\title{
MODEL PEMBELAJARAN DISCOVERY LEARNING DAN MEDIA FILM PENDEK PADA MASA PANDEMI COVID-19
}

\author{
DISCOVERY LEARNING MODEL AND SHORT FILM MEDIA DURING \\ THE COVID-19 PANDEMIC
}

SITI REJEKI

SMAN 53 Jakarta

\begin{abstract}
Received: March 09, 2021

The purpose of the study was to improve student achievement and motivation to learn English Revised: September 30, 2021 in carrying out learning from home through discovery learning models and short film media. Accepted: November 26, 2021 Classroom action research is the method used. Class X SMA Negeri 53 Jakarta, totalling 35 students as research subjects. Questionnaires, observations, and assignments as research instruments as well as quantitative and qualitative descriptive as data analysis techniques. The results of the study concluded that the students' motivation in improving achievement during learning from home was proven by the appearance of a short recount text film about the biography of Indonesian heroes in the first cycle, the lowest score was 70 and in cycle 2 the score was 50, from 35 students in two cycles the highest score was 94 . This model can encourage students to be more active in learning
\end{abstract}

\begin{abstract}
Abstrak.
Tujuan penelitian ini adalah untuk meningkatkan prestasi peserta didik dan motivasi belajar Bahasa Inggris dalam melaksanakan pembelajaran dari rumah melalui model discovery learning dan media film pendek, siswa diharap mampu mensosialisasikan materi yang didapat dengan kehidupan nyata sebagai life-skill.Penelitian tindakan kelas adalah metode yang digunakan. Siswa kelas X SMA Negeri 53 Jakarta yang berjumlah 35 orang siswa sebagai subjek penelitian. Instrumen penelitian angket, pengamatan, dan penugasan sebagai instrumen penelitian serta deskriptif kuantitatif dan kualitatif sebagai teknik analisa data. Berdasarkan nilai pada siklus | 0,48 dikategorikan positif, dan nilai pada siklus || 0,52 dikategorikan sangat positif sebagai hasil penelitian yang menyimpulkan adanya motivasi siswa dalam meningkatkan prestasi selama pembelajaran dari rumah. Hasil penampilan membuktikan film pendek recount text tentang biography tokoh pahlawan Indonesia pada siklus I hasil nilai terendah 70 dan pada siklus 2 nilai 50 ,dari 35 siswa pada dua kali siklus nilai tertinggi 94. Model discovery learning dan media film pendek dapat mendorong siswa lebih giat belajar dan merupakan media belajar yang menyenangkan karena mereka dapat bermain peran di masa pembelajaran dari rumah adalah kesimpulan yang penulis simpulkan. Adanya penyampaian pesan yang dapat dipahami oleh peserta didik serta menumbuhkan kreativitas peserta didik dan guru sehingga tujuan pembelajaran tercapai merupakan kata kunci dalam menerapkan metode ini

Keywords: Learning Model, Discovery Learning, Short film, character biography, learning motivation

Kata kunci: $\quad$ Model Pembelajaran, Discovery Learning, Film pendek, biography tokoh, motivasi belajar
\end{abstract}

$\left(^{\star}\right)$ Corresponding Author: alghifaridear94@gmail.com

How to Cite: Rejeki, S., (2021). Model Pembelajaran Discovery Learning Dan Media Film Pendek Pada Masa Pandemi Covid-19. Jurnal Lingkar Mutu Pendidikan, 18 (2), 200-203. https://doi.org/10.54124/jlmp.v18i1.32

\section{PENDAHULUAN}

Salah satu negara terdampak positif virus corona (Covid-19), yaitu Indonesia. Saat kasus pertama diumumkan langsung oleh Presiden Joko Widodo pada 2 Maret 2020 di Istana Kepresidenan, Jakarta. (Sumber Jakarta.com). Hal ini sangat berpengaruh pada dunia pendidikan dan masih berlangsung sekarang. Kondisi ini merupakan situasi terpuruk yang dialami oleh peserta didik maupun pendidik yang harus dihadapi karena proses belajar mengajar harus berjalan serta menghasilkan lulusan yang mempunyai life-skill apapun situasinya.

Pada Rabu (02/09/2020) dalam rapat koordinasi (rakor) bersama Kepala Daerah seluruh Indonesia tentang Kebijakan Pembelajaran di Masa Pandemi COVID-19, dijelaskan oleh Mendikbud, 
bahwa selama pandemi COVID-19 yang utama adalah kesehatan dan keselamatan peserta didik, pendidik, tenaga kependidikan, keluarga, dan masyarakat secara umum, serta mempertimbangkan tumbuh kembang peserta didik dan kondisi psikososial dalam upaya pemenuhan layanan pendidikan di masa pandemi dalam prinsip kebijakan pendidikan.

Untuk menghadapi kendala pembelajaran di masa pandemi COVID-19, pada tanggal 7 Agustus 2020, berbagai kebijakan dan inisiatif seperti Revisi Surat Keputusan Bersama (SKB) Empat Menteri, dikeluarkan oleh Pemerintah untuk menyesuaikan kebijakan pembelajaran di era pandemi saat ini. Selain itu, di masa darurat terkait kurikulum, sekolah diberi keleluasaan untuk memilih kurikulum yang sesuai dengan kebutuhan pembelajaran siswa di masa pandemi, diputuskan oleh Menteri Pendidikan dan Kebudayan.

Pembelajaran kreatif dan inovatif pondasi dasar untuk mewujudkannya berada ditangan peserta didik dan pendidik, dari pengalaman yang penulis alami di SMA Negeri 53 Jakarta. Ditarik kesimpulan adanya tiga persoalan utama yaitu: 1) kurangnya kemauan siswa belajar di rumah, 2) rasa jemu berada didalam rumah, 3) capaian akademik yang kurang maksimal. Jika hal ini tidak ditindaklanjuti, akan mengakibatkan banyak persoalan bagi peserta didik, pendidik, dan sekolah. Untuk peserta didik berperngaruh pada capaian akademik yang rendah, karena mereka jenuh belajar dari rumah.Untuk pendidik guru merasa tidak berhasil dalam meningkatkan mengantarkan peserta didik mengapai cita-cita mereka dan menghambat kreativitas peerta didik. Untuk sekolah akan berpengaruh hasil capaian akademik semakin rendah.

Proses belajar dalam pembelajaran dari rumah dipengaruhi oleh banyak faktor. Siswa tidak semata-mata mempengaruhi belajar, beberapa faktor dapat mempengaruhi. Muhibbin Syah (2006: 144) mengelompokan faktor-faktor yang mempengaruhi proses belajar dalam tiga bagian, yaitu: 1) Faktor internal (faktor dari dalam peserta didik), merupakan keadaan atau kondisi jasmani dan rohani peserta didik; 2) faktor eksternal (faktor dari luar peserta didik), yaitu kondisi lingkungan di sekitar siswa; 3) faktor pendekatan belajar (approach to learning), metode yang digunakan peserta didik dalam melakukan kegiatan mempelajari materi-materi pelajaran. Berbagai persoalan yang dapat mengganggu bila tidak diatasi selalu diiringi dalam kegiatan belajar mengajar. Oleh karena itu, di SMA Negeri 53 Jakarta menggunakan silabus kondisi khusus dapat mengatasi berbagai persoalan seperti yang diharapkan. Subjek belajar yang maksimal, seperti faktor faktor materi, faktor lingkungan, faktor instrumental, dan faktor individual. Selama satu semester bukan kegiatan belajarnya tetapi prestasi belajar atau hasil belajarnya di dalam penelitian ini. Dengan melihat tingkat pendidikan orangtuanya, apakah ada perbedaan prestasi belajar selama satu semester menggunakan silabus kondisi normal dan kondisi khusus yang akan diketahui oleh penulis, diantara kedua kelas tersebut manakah yang lebih baik jika ada.

Untuk tercapainya pembelajaran yang menyenangkan metode pembelajaran discovery learning adalah metode yang bisa diaplikasikan, serta dikolaborasikan dengan media film pendek. (Daryanto 2017) dikatakan bahwa model mengajar yang dilaksanakan oleh guru dengan cara mengatur proses belajar dengan sedemikian rupa sehingga peserta didik mendapatkan pengetahuan yang sebelumnya belum diketahui dan sebelumnya dengan cara tidak disampaikan terlebih dahulu akan tetapi peserta didik menemukannya secara mandiri, yaitu discovery learning.

Melalui metode ini peserta didik didesain untuk bermain peran dengan membuat film pendek ketika berlangsungnya proses belajar. Film pendek ini dibuat dengan baik dalam situasi yang menyenangkan dan dapat mendorong capain prestasi peserta didik. Membuat film pendek juga dapat diterapkan untuk semua mata pelajaran. Tetapi dalam penelitian ini penulis menitikberatkan penerapan metode pada pembelajaran Bahasa Inggris pada materi recount text biography tokoh pahlawan Indonesia yang diperankan dan ditampilkan melalui video karena materi yang ada sangat menginspirasi situasi saat ini yang mana peserta didik harus selalu diberi pengertian dan pemahaman tentang biografi pahlawan yang telah mendahului kita sehingga mereka bisa meniru dan meneladani. Adapun tujuan dalam penelitian ini adalah untuk menaikan prestasi siswa dan motivasi belajar Bahasa Inggris dalam melaksanakan pembelajaran dari rumah melalui model discovery learning dan media film pendek. Dalam pembelajaran Bahasa Inggris saat ini melalui model discovery learning dan media film pendek, siswa diharap mampu mensosialisasikan materi yang didapat dengan kehidupan nyata sebagai lifeskill bagi SMA Negeri 53 Jakarta siswa kelas $X$. 


\section{METODE PENELITIAN}

Penelitian Tindakan kelas yaitu meneliti yang penulis akan lakukan dengan menggunakan model penelitian yang mengacu pada urutan penelitian yang disampaikan oleh model dasar yang kemudian dikembangkan oleh ahli-ahli lain yaitu Model Kurt Lewin. Empat komponen kegiatan yang dipandang sebagai satu siklus, yaitu: perencanaan (planning),tindakan (acting), pengamatan (observing), dan refleksi (reflecting) yaitu penelitian tindakan yang dikemukakan oleh Kurt Lewin menurutnya.

Desain tindakan kelas meneliti Model Hopkins.Desain ini berpijak pada desain model penelitian tindakan kelas pendahulunya. Mengambil start - audit - perencanaan konstruksi - perencanaan tindakan (target, tugas, kriteria keberhasilan) - implementasi dan evaluasi: implementasi (menopang komitmen: cek kemajuan; mengatasi problem) -cek hasil - pengambilan stok - audit dan pelaporan, desain yang disusun oleh Hopkins (1993:191).

Penelitian dilakukan di SMA negeri 53 Jakarta pada Bulan Maret - Mei 2020 saat pandemi COVID-19 berlangsung. Sampel penelitian siswa kelas X IPA4 yang berjumlah 35. 2 siklus dilakukan penelitian. 6 langkah setiap siklus, antara lain start, audit, perencanaan konstruk, perencanaan tindakan (target, tugas, kriteria keberhasilan) implementasi dan evaluasi.

Untuk mendapatkan hasil pengamatan dan refleksi data dilakukan dengan dua acara, yaitu: 1) Analisis Data Respon peserta didik dikalkulasikan dengan skala sikap yang dimaksudkan untuk mengetahui kecenderungan perilaku dan sikap peserta didik mengenai pertanyaan yang diberikan. Peserta didik merespon dengan rentang skor sangat mampu (SM), mampu (LM), tidak mampu (CM) sangat tidak mampu (STM). Setiap Butir Pernyataan Untuk Skor Respon Siswa yaitu RS $=2 x \mathrm{nSM}+$ nM -nTM -2x 2x nSKM (RS = respon siswa, $S M=$ sangat mampu, $M=$ mampu, TM = tidak mampu , SKM = sangat kurang mampu; 2) Nilai ulangan post test pada akhir siklus diperoleh dari hasil analisis belajar siswa

Nilai tertinggi dan nilai terendah diperoleh dari hasil akhir siklus dinyatakan berhasil jika (kategori positif) nilainya lebih dari 0 dan minimal $75 \%$ jumlah siswa yang tuntas, dikategorikan ketuntasan klasikal. Keduanya merupakan indikator kinerja penelitian

\section{HASIL DAN PEMBAHASAN}

Pada model pembelajaran menggunakan model discovery learning yang dikreasikan dengan film pendek hasil belajar peserta didik. dengan Langkah kerja sintak model discovery learning yaitu Stimulation (Stimulasi/Pemberian Rangsangan), problem Statement (Pernyataan/Identifikasi Masalah), data Collection (Pengumpulan Data) data Processing (Pengolahan Data), verification (Pembuktian), generalization (Penarikan Simpulan)

Masalah yang diangkat dalam penelitian yaitu apakah model discovery learning dan media film pendek bisa menaikan prestasi peserta didik dan motivasi belajar bahasa Inggris dalam melaksanakan pembelajaran di rumah melalui model discovery learning materi recount biografi tokoh pahlawan dengan pembelajaran dari rumah. Untuk mengatasi persoalan, guru menentukan terlebih dahulu tujuan dari pembelajaran discovery yang akan dilakukan agar proses pembelajaran dapat memenuhi hasil belajar yang telah ditentukan di tahap ini. Dengan model discovery learning merumuskan masalah-masalah yang terdapat dalam kelas dan menentukan target dari proses belajar-mengajar,misalnya. Selanjutnya identifikasi karakteristik dilakukan peserta didik. Di tahap ini mengidentifikasi setiap karakter siswa yang ada di kelas X IPA 4 dilakukan oleh guru. Setiap karakteristik yang berbeda dari peserta didik agar dapat disesuaikan dengan bahan ajar dan model discovery learning seperti apa yang harus diterapkan pada peserta didik kelas X IPA 4 perlu diidentifikasi.

Berikutnya adalah Pelaksanaan Tahapan Pembelajaran dengan cara penyajian materi dengan pola jarak jauh dikelola oleh kelas. Untuk diinformasikan materi membuat film pendek siswa memilih sesuai dengan kesukaannya tentang biografi tokoh pahlawan seperti BJ Habibie, kemudian proses pembuatan film pendek setelah itu pengumpulan film pendek yang waktunya sudah ditentukan oleh kesepakatan bersama, dilanjutkan dengan proses penilaian, proses ini adalah hasil akhir yang diperoleh peserta didik. Tahapan selanjutnya adalah kegiatan pembelajaran yang berupa tugas untuk dipelajari siswa berupa contoh-contoh, ilustrasi, dikembangkan bahan belajar. serta pengaturan dari yang sederhana ke kompleks, dari yang konkret ke abstrak, atau dari tahap enaktif, ikonik sampai ke simbolik yaitu topik-topik pelajaran. 
Tugas ini dilakukan secara berkelompok dan beban berekspresi, dan penilaian proses dalam Model Pembelajaran Discovery, penilaian dapat dilakukan dengan menggunakan format hasil kerja yang mencakup tata suara, expresi pemeranan, tata letak dan blocking serta moving dan gerakan

Dalam hasil kegiatan, pada materi pelajaran yang akan disampaikan melalui penggunaan media PowerPoint, dipersiapkan perlengkapan dan media yang digunakan selama proses pembelajaran, seperti: laptop, proyektor, lembar kerja siswa, dan alat tulis, memeriksa kesiapan siswa, membuka pelajaran dengan melakukan doa bersama, dan mengucapkan salam, melakukan apersepsi yang dilakukan oleh guru

Di kegiatan inti yaitu peserta didik dibagi menjadi beberapa bagian oleh guru, memberi lembar kerja untuk mengisi dialog yang akan dipresentasikan dalam bentuk recount text tentang biografi, kebebasan memilih cerita yang mereka sukai diberikan ke siswa untuk ditampilkan (sintak memberi rangsangan pada siswa). Selanjutnya pedoman kegiatan pembelajaran disampaikan oleh guru dari rumah kali ini yang akan dilakukan pada pembelajaran. Adapun pedomannya yaitu setiap peserta didik diberi pilihan recount text tentang biografi tokoh pahlawan sesuai langkah discovery learning sebagai sintaks rangsangan. Kemudian setiap peserta didik untuk waktu dua hari diminta membuat text biografi tokoh pahlawan, setiap peserta didik menceritakan kembali text recount dalam bentuk film pendek yang dihafalkan kemudian dipresentasikan kemudian direkam dalam bentuk video, yang terakhir setiap peserta didik mengirimkan video film pendek dalam bentuk recount text biografi pahlawan lewat whatsapp atau email atau google drive.

Setelah melakukan kegiatan pembuatan film pendek setiap ketua kelompok mengumpulkan dan guru melakukan penilaian terhadap proses bermain peran film pendek yang telah dibuat dalam bentuk video dari nilai yang didapat dilihat bagaimana motivasi peserta didik dalam mengikuti pembelajaran dari rumah. Untuk menilai motivasi peserta didik dalam proses bermain peran film pendek guru menghadiahkan peserta didik berupa voucher yang mendapatkan nilai paling bagus serta kelompok yang mendapat nilai cukup. Kriteria penilaian adalah adanya kolaborasi dalam penampilan, fasih dalam mengucapkan lafal Bahasa Inggris. Adanya kreativitas kelompok serta adanya improvement kelompok serta adanya inovasi kelompok dalam bermain peran.

\section{SIMPULAN DAN SARAN}

Sesuai dengan hasil dapat disimpulkan pembelajaran yang telah dilaksanakan bahwa penerapan discovery learning dan media sebagai model pembelajaran film pendek menaikan prestasi peserta didik dan motivasi belajar Bahasa Inggris dalam melaksanakan pembelajaran dari rumah. Adanya peningkatan respon peserta didik dengan model discovery learning terhadap pembelajaran diperoleh nilai sangat positif pada siklus I dengan skor 0,48, sedangkan nilai positif pada siklus II dengan skor 0,52 . Berdasarkan pemantauan pembelajaran dari rumah dengan metode discovery learning dan media film pendek diperoleh skor ter kecil 70 pada siklus I skor 50 pada siklus 2 dan skor tertinggi 94 dari 35 peserta didik sehingga dapat disimpulkan sudah melebihi target KKM pada KD recount text sehinga dengan hasil tersebut ada pesan tersurat bagi pendidik dengan menggunakan pembelajaran discovery learning dan media film pendek menjadi media pembelajaran yang menyenangkan pada mata pelajaran Bahasa, metode Discovery learning dapat digunakan sebagai referensi pembelajaran untuk semua mata pelajaran yang lain.

\section{PUSTAKA ACUAN}

Jakarta .com [2020], Indonesia menjadi salah satu negara positif virus corona (Covid-19)

Jakarta, Kemendikbud [2020] Prinsip kebijakan pendidikan di masa Pandemi COVID-19

Syah Muhibbin, 2006. Psikologi Belajar, Jakarta: PT. Raja Grapindo Persada.

Daryanto, Karim Syaiful, [2017]. Pembelajaran Abad 21. Gava Media.Yogyakarta

Kurt Lewin M. Keller. [1992], Instructional Design Theory and Models : A Overview of Their Current Status, Charles M. Regeluth (ed), Lawrence Erlbaum Associates, London.

Hopkins. [1993]. Desain Penelitian Tindakan Kelas (Model Ebbut).Yogyakarta :Pustaka Belajar

Rizkiani Dwi. 2016. Penerapan Model Dicovery Learning Untuk Menumbuhkan Sikap Rasa Ingin Tahu dan Hasil Belajar Siswa Pada Subtema Macam macam Sumber Energi. Bandung: Universitas Pasundan Arikunto, Suharsimi. [2010].

Tujuan Penggunaan Model Pembelajaran Discovery Learning (2016)http://www.wawasanpendidikan.com/2016/01/PengertianTujuanMacamMacam-Proses-Keunggulan-serta-Kelemahan-Metode-InquiryDiscovery-Learning.html. Diakses dari laman web tanggal 22 Februari 2017 Pukul 08.00

Teori-teori Discovery Learning [2013]https://en.wikipedia.org/wiki/Discovery_learning. Diakses dari laman web tanggal [20 Februari 2017] Pukul 09.00 